UDC: $57.017 .3: 546.48$

\title{
FATTY ACID COMPOSITION OF CORN AND WHEAT PLANT SHOOTS UNDER THE ACTION OF SALICYLATE IN DROUGHT CONDITIONS
}

\author{
M. S. Kobyletska \\ Ivan Franko National University of Lviv, 4, Hrushevskyi St., Lviv 79005, Ukraine \\ ${ }^{*}$ Corresponding author e-mail: myroslava.kobyletska@Inu.edu.ua
}

Kobyletska M.S. Fatty acid composition of corn and wheat plant shoots under the action of salicylate in drought conditions. Studia Biologica, 2020: 14(3); 91-104 • DOI: https://doi. org/10.30970/sbi.1403.629

Background. Salicylic acid is a phenolic compound of natural plant origin with hormonal properties. Salicylic acid is involved in the formation of plant resistance to stressors of biotic and abiotic nature. Drought is one of the most common stressors inhibiting growth, development and yield of plants. Fatty acids are important components of membrane organelles and plasmalemma. Changing the ratio of saturated and unsaturated fatty acids affects the properties of cell membranes and is an important component of the formation of plant resistance to stressors such as low or high temperatures and drought.

Methods. To study the changes in fatty acid composition that occur in plants under the action of salicylic acid and drought, we determined the content of fatty acids in the shoots of plants using gas-liquid chromatography. The effect of salicylic acid on the content of saturated and unsaturated fatty acids in shoots of 12-day plants Zea mays L. and Triticum aestivum $\mathrm{L}$. in the drought conditions was investigated. It was found that the content of saturated and unsaturated fatty acids in the shoots of Zea mays L. and Triticum aestivum $\mathrm{L}$. decreased under drought conditions. At the same time, salicylic acid in the concentration of $0.5 \mathrm{mM}$ initiated an increase in the content of these compounds under stressful conditions. The lipid unsaturation index - the ratio of saturated and unsaturated fatty acids - was also determined.

Results. The increase in lipid unsaturation index under the influence of the salicylic acid in the shoots of Zea mays L. was insignificant. Drought caused a significant decrease in this indicator mainly due to a decrease in the pool of saturated fatty acids. Under the combined influence of drought and salicylic acid, lipid unsaturation index significantly increased relative to that of drought. The increase in lipid unsaturation

(ㄷ 2020 M. S. Kobyletska; Published by the Ivan Franko National University of Lviv on behalf of Біологічні Студії / Studia Biologica. This is an Open Access article distributed under the terms of the Creative Commons Attribution License (http://www.budapestopenaccessinitiative.org and Creative Commons Attribution 4.0 License), which permits unrestricted reuse, distribution, and reproduction in any medium, provided the original work is properly cited.

ISSN 1996-4536 (print) • ISSN 2311-0783 (on-line) • Біологічні Студії / Studia Biologica • 2020 • Том 14/№3 • С. 91-104 
index correlated with changes in the accumulation of unsaturated and saturated fatty acids in the shoots of the studied plants. Determination of lipid unsaturation index in Triticum aestivum L. showed that in plant shoots under the conditions of moisture deficiency there is also a significant decrease in lipid unsaturation index. This is mainly due to a sharp decrease in the content of unsaturated fatty acids. At the same time, under the combined influence of salicylic acid and drought, the lipid unsaturation index decreases even more.

Conclusion. Despite similar trends in the impact of salicylic acid and drought on the content of saturated and unsaturated fatty acids in the two studied plant species, some differences were observed: under stressful conditions, salicylic acid caused an increase in lipid unsaturation index in Zea mays L. and a significant decrease of this index in Triticum aestivum $\mathrm{L}$.

Keywords: Zea mays L., Triticum aestivum L., salicylic acid, drought, fatty acids

\section{INTRODUCTION}

There are a number of plant-based plant metabolites involved in forming a response to the influence of adverse environmental factors of biotic and abiotic origin. In particular, they include carbohydrates (glucose, sucrose, fructose) and amino acids (proline, pool of free amino acids) [28]. Since salicylic acid (SA) acts as a signaling molecule in the plant organism, it triggers a number of biochemical changes that lead to the modification of virtually all parts of plant metabolism.

Fatty acids play a key role in plant metabolism. Not only do they ensure the structural integrity of plant cells being the most important components of all membranes, but also serve as a source of energy for various metabolic processes [21]. In addition, some fatty acids and their metabolites (cyclic and acyclic products) are mediators of signaling. They can play the role of both intracellular and extracellular signal path components [18].

An important function of fatty acids is their participation in the formation of plant stability. They are elements of a number of metabolic changes that activate the defense mechanisms of the plant organism to different stress factors. First of all, fatty acids are biosynthetic precursors of cuticle components [13]. In addition, they are synthesized from linolenic acids, phytohormone jasmonic acid (JA) and methyl ester methyl jasmonate. Mainly, this process is triggered by mechanical damage of plant cells and is accompanied by the hydrolysis of cellular phospholipid membranes [30]. Accordingly, these transformations underlie the participation of fatty acids and their derivatives in the induction of protective reactions of plants when being penetrated by phytopathogens or consumed by herbivores [27, 33].

The functions of fatty acids in the formation of stress resistance of plants are not limited only by the effects of biotic stress. Actually, any stress factor causes changes in the fluidity of plant membranes. This modification occurs due to the release of linolenic acid from membrane lipids, as well as changes in the content of unsaturated fatty acids. Changes in the activity of lipases and desaturases of fatty acids play an important role in these reactions. Regulation of the membranes fluidity helps to create the environment which is necessary for maintaining the functional activity of integral proteins under stress. Changes in oleic acid content in chloroplasts are a key response for expression

ISSN 1996-4536 (print) • ISSN 2311-0783 (on-line) • Біологічні Студії / Studia Biologica • 2020 • Том 14/№3 • C. 91-104 
of Arabidopsis defensive reactions to the penetration of phytopathogens. Modification of oleic and linolenic acid levels affects regulation development and synthesis of mycotoxins Aspergillus sp. [32].

Determining the effect of SA on the fatty acid composition of plant organs in drought conditions will allow using the SA to increase the resistance of plants to stress factors and contribute to better understanding of the nature of this effect.

The aim of this study was to investigate the effect of SA on the fatty acid composition of wheat and corn shoots under drought conditions.

\section{MATERIALS AND METHODS}

In order to investigate the changes in fatty acid composition that occur in plants under the action of SA and drought, we determined the content of fatty acids in the shoots of plants using the method of gas-liquid chromatography [25].

The objects of our study were maize plants (Zea mays L.) of Zhovta Zubovydna variety and wheat (Triticum aestivum L.) of Podolyanka variety. The seeds were presoaked in a solution of SA $(50 \mathrm{mM})$ for $3 \mathrm{~h}$. First, the seeds germinated in an incubator, and on the $3 \mathrm{rd}$ day of growth were transplanted into plastic pots $(\mathrm{d}=14 \mathrm{~cm})$. Plants were grown on soil substrate, whose humidity was maintained at $60 \%$ of full moisture capacity - optimal water supply. The model of drought was created by the simultaneous cessation of irrigation (30 \% of soil moisture capacity) during 12 days. Upon termination of the drought, soil moisture in the pots was adjusted to $60 \%$ of full capacity. The control plants were grown from the seeds not pre-treated with salicylic acid under the conditions of optimal water supply $(60 \%)$. The samples for our study were taken from the leaves of wheat and corn after 12-days of drought period.

$0.5-1 \mathrm{~g}$ of plant tissues were used for analysis. The test biological material in the vial was extracted according to Wother with a mixture of chloroform - methanol - hydrochloric acid (200: 100: 1 by volume) in a ratio of 1:20 for $2 \mathrm{~h}$. The extracted lipids were saponified, and the obtained fatty acids were methylated. After extraction, $4 \mathrm{~mL}$ of distilled water was added to the mixture. After stratification of the mixture with a water jet pump, the upper water-methanol layer was removed and discarded, and the lower one was pipetted onto a paper filter with a blue stripe and filtered into a heat-resistant glass tube.

The obtained methyl esters were introduced into the evaporator of the gas-liquid chromatographic apparatus. The results of gas chromatographic studies were calibrated.

Chloroform from the test tube was evaporated in a stream of dried nitrogen in a water bath in a vacuum cabinet $\left(37-40^{\circ} \mathrm{C}\right)$, and to its contents were added $4-5$ drops of $2 \mathrm{~N}$ alcohol (methyl) solution of sodium metal. The mixture was placed in a boiling water bath. After $30 \mathrm{sec}$ from the start of boiling, $1.5 \mathrm{~mL}$ of distilled water was added to the contents of the tube. The boiling was continued until the smell of alcohol disappeared (about $30 \mathrm{~min}$ ). After boiling, the tube was cooled. After methylation was complete, the methanol was evaporated from the test tube in a vacuum oven at $45-50{ }^{\circ} \mathrm{C}$. Then the fatty acid methyl esters in the test tube were dissolved in a small amount of hexane. Then, using a microsyringe, $1 \mu \mathrm{L}$ of hexane solution of fatty acid methyl esters was injected into the evaporator of the gas-liquid chromatographic apparatus, which has a column selective for long-chain fatty acids. To obtain quantitative data, the results of chromatographic studies were calibrated.

ISSN 1996-4536 (print) • ISSN 2311-0783 (on-line) • Біологічні Студії / Studia Biologica • 2020 • Том 14/№3 • С. 91-104 
Experiments were repeated three times with three parallel staging for each variant of the experimental and control conditions. The obtained data were processed using the Microsoft Excel 2010 program. To evaluate the significance of the difference between the statistical characteristics of the two alternative sets of data, Student's coefficient $t$ was calculated. The difference was considered to be significant at $\mathrm{P}<0.05$ [16].

\section{RESULTS AND DISCUSSION}

The content of saturated and unsaturated fatty acids under drought conditions was determined. It was found that in the shoots of 12-day-old corn plants among unsaturated fatty acids dominated linolenic acid; its content varied in the range of $350-470 \mathrm{mg} / \mathrm{g}$ of dry weight (Fig. 1). The amount of palmitolenic acid was the smallest among the fatty acids of this group (5-11 $\mathrm{mg} / \mathrm{g}$ dry weight).

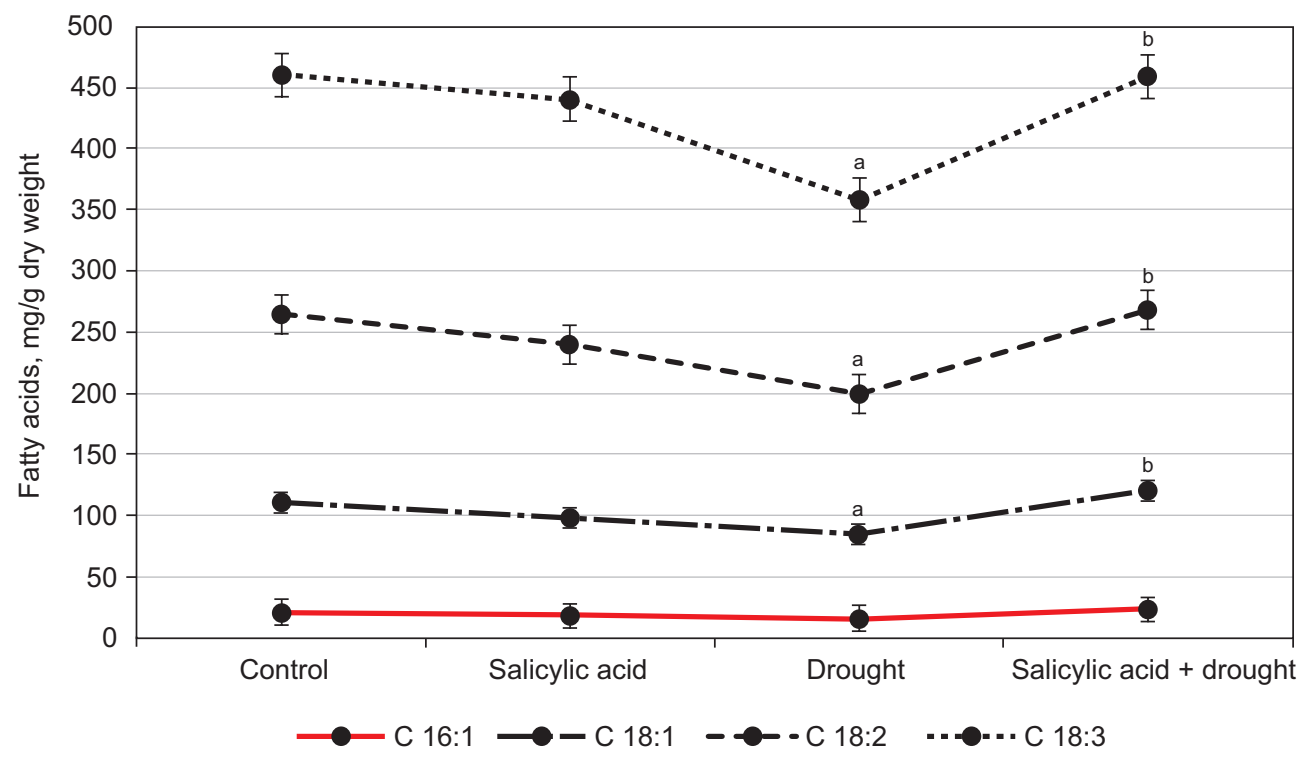

Fig. 1. Influence of salicylic acid and drought on the content of unsaturated fatty acids in the shoots of 12-day-old plants Zea mays L., mg/g dry weight.

Note here and in Fig. 2: C 16:1 - palmitoleic acid; C 18:1 - oleic acid; C 18:2 - linoleic acid; C 18:3 linolenic acid. $a-P<0.05$ (vs control); $b-\mathrm{P}<0.05$ (vs drought)

Рис. 1. Вплив саліцилової кислоти і посухи на вміст ненасичених жирних кислот у пагонах 12-добових рослин Zea mays L., мг/г сухої маси.

Примітка тут і на рис. 2: C 16:1 - пальмітоолеїнова кислота; C 18:1 - олеїнова кислота; С 18:2 лінолева кислота; С 18:3 - ліноленова кислота. а - Р <0,05 (щодо контролю); b - Р <0,05 (щодо посухи)

Under the influence of SA there was a slight decrease in the content of unsaturated fatty acids. In drought conditions, the content of these components in the shoots of plants decreased as well. However, under the combined effect of SA and drought, we observed significant increases in oleic and linolenic acids relative to the variant of exposure to drought alone.

ISSN 1996-4536 (print) • ISSN 2311-0783 (on-line) • Біологічні Студії / Studia Biologica • 2020 • Том 14/№3 • C. 91-104 
A study of the unsaturated fatty acids in Triticum aestivum L. showed that their content in drought conditions reduced much less than in Zea mays L. (Fig. 2). Among the polyunsaturated fatty acids, the content of linolenic acid underwent the greatest changes. However, the influence of SA on the accumulation of unsaturated fatty acids had a similar character: the growth regulator caused an increase in their content in moisture deficiency conditions.

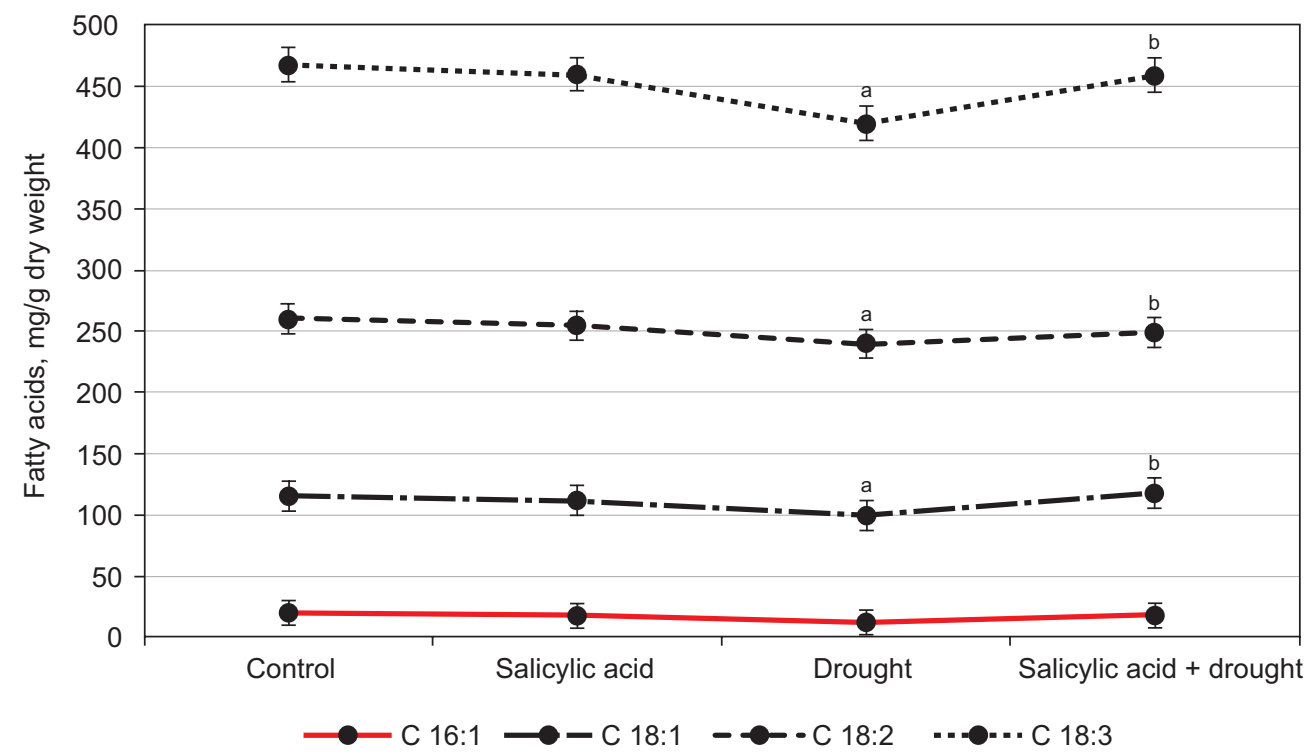

Fig. 2. Influence of salicylic acid and drought on the content of unsaturated fatty acids in the shoots of 12-day-old plants of Triticum aestivum L., mg/g dry weight. a $-\mathrm{P}<0.05$ (vs control); $\mathrm{b}-\mathrm{P}<0.05$ (vs drought)

Рис. 2. Вплив саліцилової кислоти і посухи на вміст ненасичених жирних кислот у пагонах 12-добових рослин Triticum aestivum L., мг/г сухої маси. a - P <0,05 (щодо контролю); b - P<0,05 (щодо посухи)

According to the literature, in the early stages of stress response of plants to adverse factors of biotic and abiotic origin, there is an increase in reactive oxygen species (ROS). These compounds trigger oxidative processes leading to the destruction of components of cell membranes, first of all membrane phospholipids [15]. The activation of this process with ROS causes the destruction of unsaturated fatty acids, and reduces the concentration of polar lipids and polyunsaturated fatty acids [11]. As a result, hydroperoxides are formed, which, in turn, cause the synthesis of malonic dialdehyde (MDA), in particular [20].

In our previous studies, we found that the content of TBA-active products increases sharply under drought conditions in the tissues of Zea mays L. and Triticum aestivum [14]. Obviously, these processes are the cause of a decrease in the content of unsaturated fatty acids in the drought conditions. Intensification of lipid peroxidation leads to the disturbance of membrane fluidity, disruption of ion transport and loss of enzymatic activity [12]. Thus, a reduction in the content of TBA-active products, which are most commonly used a marker of oxidative stress in higher plants [29], and an increase in the

ISSN 1996-4536 (print) • ISSN 2311-0783 (on-line) • Біологічні Студії / Studia Biologica • 2020 • Том 14/№3 • С. 91-104 
content of unsaturated fatty acids under the combined effect of SA and drought play a positive role for adaptation processes in plants under stressful conditions.

The content of saturated fatty acids in the shoots of Zea mays L. was considerably lower than that of most unsaturated acids. Only the content of palmitic acid was relatively high and ranged from 82 to $125 \mathrm{mg} / \mathrm{g}$ dry weight. Among saturated fatty acids, the content of pentadecanoic acid was the lowest (3-12 mg/g dry weight). The SA did not cause significant changes in the content of saturated fatty acids. However, in the drought conditions, the content of all fatty acids of this group significantly decreased (Fig. 3). During the pre-processing of seeds with SA in the drought conditions, a significant increase in the content of unsaturated fatty acids was observed. No changes were detected in the ratio of individual fatty acids under the influence of the studied factors.

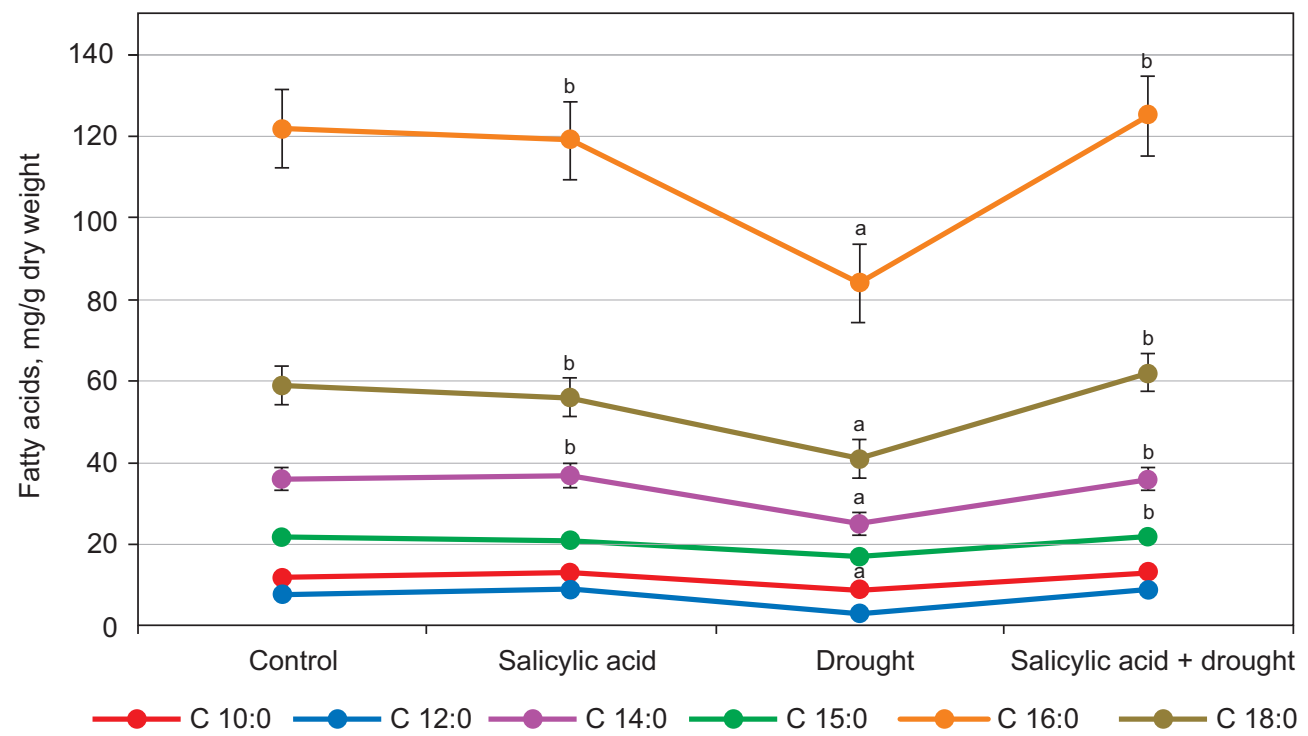

Fig. 3. The influence of the salicylic acid and drought on content of the saturated fatty acids in the shoots of 12-day-old plants Zea mays L., $\mathrm{mg} / \mathrm{g}$ dry weight.

Note here and in Fig. 4: C 10:0 - capric acid; C 12:0 - lauric acid; C 14:0 - myristic acid; C 15:0 pentadecanoic acid; C 16:0 - palmitic acid; C 18:0 - stearic acid. a - P $<0.05$ (vs control); b - P $<0.05$ (vs drought)

Рис. 3. Вплив саліцилової кислоти і посухи на вміст насичених жирних кислот у пагонах 12-добових рослин Zea mays L., мг/г сухої маси.

Примітка тут і на рис. 4: C 10:0 - каприлова кислота; C 12:0 - лауринова кислота; C 14:0 міристинова кислота, С 15:0 - пентадеканова кислота; С 16:0 - пальмітинова кислота; С 18:0 стеаринова кислота. а - P <0,05 (щодо контролю); b - P<0,05 (щодо посухи)

In the shoots of Triticum aestivum L., a slightly higher content of saturated fatty acids was found than in Zea mays L. (Fig. 4). In particular, in Triticum aestivum L., the content of lauric acid was 26-31 mg/g dry weight, while in the shoots of Zea mays L. it was 3-8 $\mathrm{mg} / \mathrm{g}$ dry weight. Under the drought conditions, a decrease in the content of unsaturated fatty acids was observed. As in the case of Zea mays L., SA caused an increase in the content of unsaturated fatty acids in the conditions of moisture deficiency.

ISSN 1996-4536 (print) • ISSN 2311-0783 (on-line) • Біологічні Студії / Studia Biologica • 2020 • Том 14/№3 • С. 91-104 


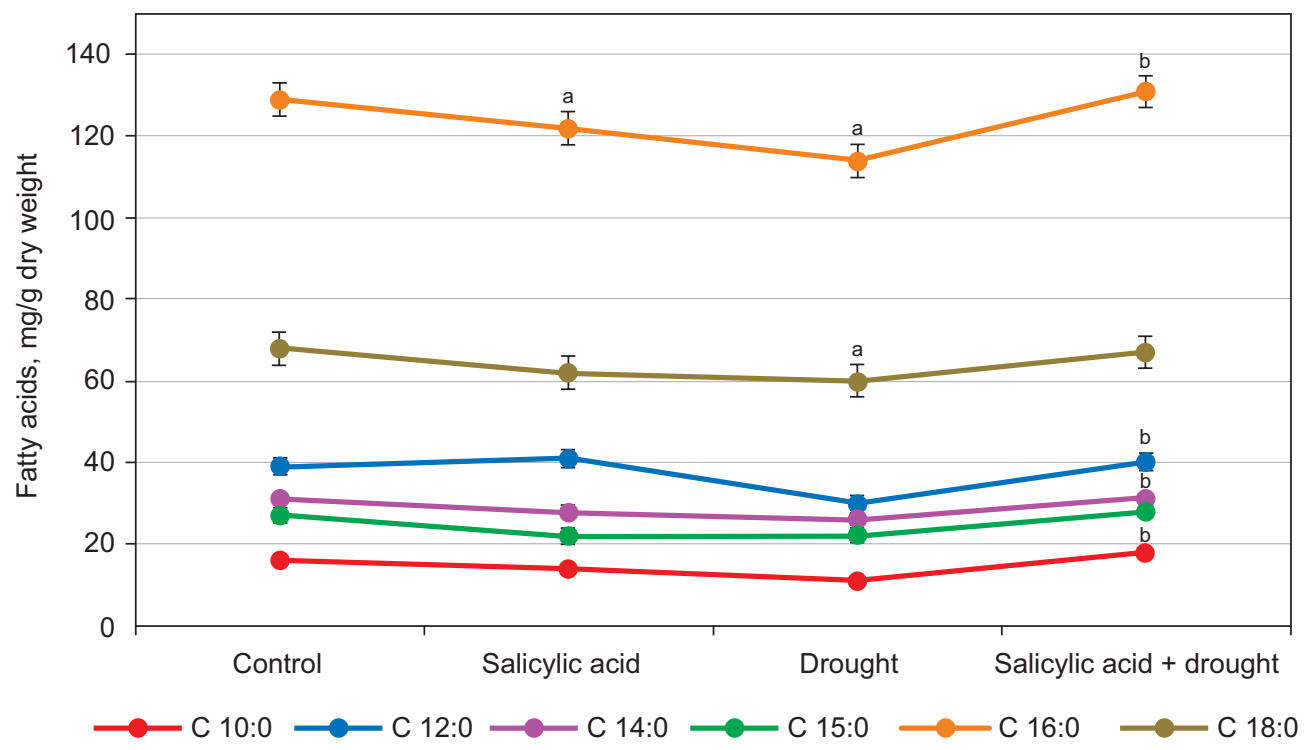

Fig. 4. The influence of the salicylic acid and drought on content of the saturated fatty acids in the shoots of 12-day-old plants of Triticum aestivum L., mg/g dry weight. a $-\mathrm{P}<0.05$ (vs control); $\mathrm{b}-\mathrm{P}<0.05$ (vs drought)

Рис. 4. Вплив саліцилової кислоти і посухи на вміст насичених жирних кислот у пагонах 12-добових рослин Triticum aestivum L., мг/г сухої маси. a - P<0,05 (щодо контролю); b - P<0,05 (щодо посухи)

Although SA and drought had a similar effect on the content of certain fatty acids, we analyzed the influence of these factors on the overall pool of saturated and unsaturated fatty acids in the studied plants.

As can be seen from the results (Fig. 5A) under the conditions of moisture deficiency, in the shoots of 12-day plants Zea mays L. there was a significant decrease in the total content of saturated and unsaturated fatty acids. The content of unsaturated fatty acids decreased by $23 \%$, and saturated ones - by $31 \%$ relative to control. SA didn't cause significant changes in fatty acid content in plants. However, under the combined effect of moisture deficiency and SA, the content of both saturated and unsaturated fatty acids was within control, i.e. SA caused their growth under stress.

A similar trend in the accumulation of fatty acids was observed in Triticum aestivum L. (Fig. 5B). In particular, in the conditions of moisture deficiency, the content of unsaturated fatty acids decreased by $11 \%$, and saturated ones - by $17 \%$, respectively. Therefore, in the drought conditions, the content of fatty acids in Triticum aestivum $\mathrm{L}$. decreased, but to a much lesser extent than in Zea mays L. The reason of a decrease in the fatty acids content in the drought conditions is the inhibition of their biosynthesis. This process occurs in plants under the impact of water stress [7] and is one of the metabolic disorders under these conditions.

Under the impact of SA, significant changes in the total content of fatty acids have not been detected. In both studied species under the combined effect of SA and drought, an increase in the content of saturated and unsaturated fatty acids, which significantly exceeded the content of these compounds in drought conditions, was observed.

ISSN 1996-4536 (print) • ISSN 2311-0783 (on-line) • Біологічні Студії / Studia Biologica • 2020 • Том 14/№3 • С. 91-104 

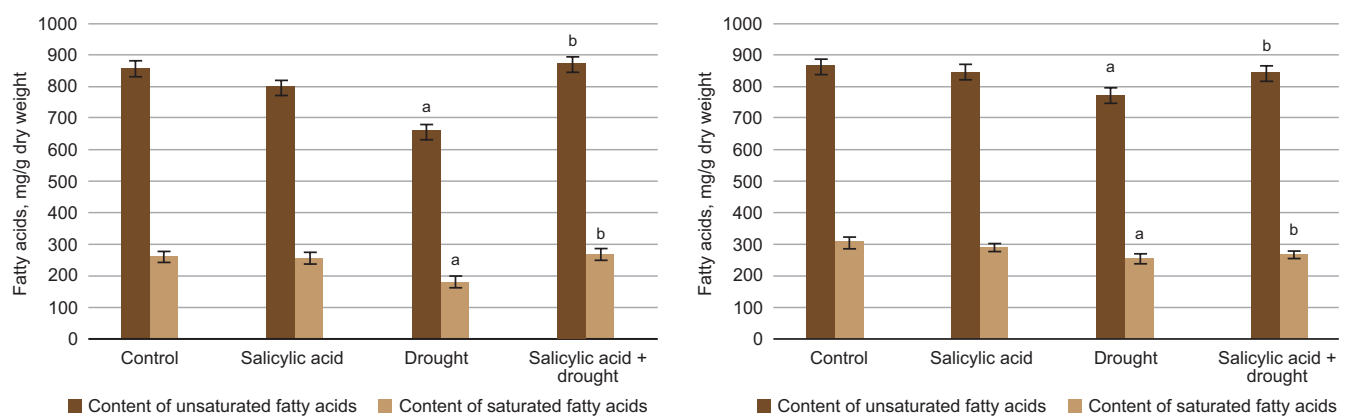

Fig. 5. The influence of the salicylic acid and drought on the content of saturated and unsaturated fatty acids in the shoots of 12-day-old plants of Zea mays L. $(\boldsymbol{A})$ and Triticum aestivum L. (B), $\mathrm{mg} / \mathrm{g}$ dry weight. $\mathrm{a}-\mathrm{P}<0.05$ (vs control); $\mathrm{b}-\mathrm{P}<0.05$ (vs drought)

Рис. 5. Вплив саліцилової кислоти й посухи на вміст насичених і ненасичених жирних кислот у пагонах 12-добових рослин Zea mays L. (A) i Triticum aestivum L. (B), мг/г сухої маси. a - P<0,05 (щодо контролю); $\mathrm{b}-\mathrm{P}<0,05$ (щодо посухи)

It was found that under the drought conditions in the shoots of Zea mays L. and Triticum aestivum L., the content of saturated and unsaturated fatty acids decreased.

At the same time, SA caused an increase of these compounds under stressful conditions. In accordance with literature, accumulation of fatty acids can affect a number of factors, particularly, the activity of the enzyme epsiloncyclase, which is involved in the biosynthesis of carotenoids. It was established that a decrease in lycopenepsiloncyclase activity in transgenic rapeseed contributed to the accumulation of some carotenoids, namely $\beta$-carotene, zeaxanthin, violaxanthin and lutein. At the same time, in the studied samples, a lower level of total fatty acids, as well as some changes in their ratio were recorded [36]. The composition of membrane lipids as well as the degree of unsaturation of fatty acids, which are part of them, may change under the influence of a number of environmental factors: the intensity of light, hypo- and hyperthermia, the presence of osmotically active substances, as well as organic or inorganic salts [2]. Plants that with changes in the fatty acid composition of lipids, due to the influence of SA, may have a higher adaptability to stressful environmental conditions. One of the main strategies by which plants adapt to external factors in stable temperature conditions are changes in the degree of unsaturation of fatty acids in membrane lipids. Membranes, especially plasmalemma and membranes of chloroplasts are very sensitive to environmental factors. As a response to changes, plants can regulate the glycerolipid composition of cell membranes in order to maintain their integrity and optimal fluidity [22, 35]. An increase in the amount of fatty acids observed in the shoots of the studied plants under the combined effect of SA and drought is obviously the result of the activation of their biosynthesis, as the degree of membranes saturation with fatty acids can significantly alter plant tolerance to the conditions of moisture deficiency [17].

Proline - an amino acid with a wide range of osmoprotective characteristics - also has a positive impact on stabilization of membrane structures. We have found the growth of proline in plant tissues under the influence of SA [19]. An increase in the content of proline under the action of SA under stress is positive, because this compound not only acts as an osmoprotector, but also reduces protein dehydration. Proline causes an increase in the membranes hydration as well as stabilization of their structure [9, 24].

ISSN 1996-4536 (print) • ISSN 2311-0783 (on-line) • Біологічні Студії / Studia Biologica • 2020 • Том 14/№3 • C. 91-104 
Drought resistance in plants is developed not only as a result of the process of morphological of adaptation, but also due to reactions at the biochemical and genetic levels [1]. The cellular level of adaptation is especially important because it is involved in maintaining homeostasis in plants that are resistant to stressful environments. At the same time, in the cells of sensitive species, a rapid irreversible damage to cellular components occurs, mainly by the destruction of membranes [3, 6]. In fact, cellular membranes are the main targets of degradation processes caused by the lack of moisture. It has been shown that drought reduces the level of membrane lipids [7, 31, 34] by inhibiting their biosynthesis [7, 8], and, on the other hand, by activating lipolytic and peroxidative activity $[10,26]$.

The development of mechanisms of resistance to stress factors in plants, particularly to drought, depends on the ability of cell membranes to modify lipid composition, ratio and content of fatty acids. Drought has been proved to cause disturbances of lipid metabolism and integrity of plant cell membranes [4, 23], as well as a reduction in the content of saturated and unsaturated fatty acids. SA eliminates the stressors effect on the content of these compounds in plant tissues, which can help to stabilize the fatty acid composition and the structure of cell membranes.

In our previous studies, an ascending growth of carotenoids under conditions of moisture deficiency was found. This may be the cause of the reduction of the content of saturated and unsaturated fatty acids in the shoots of Zea mays L. under these conditions. Like Zea mays L., shoots of Triticum aestivum L. were characterized by high content of unsaturated fatty acids. In Zea mays L., the content of unsaturated fatty acids exceeded the content of saturated ones by 3,3 times; in Triticum aestivum L. - more than by 2.5 times (Fig. 5). The ratio of saturated and unsaturated fatty acids is an important indicator of the adaptive potential of plants to face stressful environmental conditions [5, 37]. Therefore, at the next stage of studies we determined the lipid unsaturation index (LUI). LUI in shoots of Zea mays L. was quite high and varied within 27-32 \% (Fig. 6 A). The increase in LUI under the influence of SA was insignificant. Drought caused a significant decrease in this indicator mainly due to reducing the pool

$\boldsymbol{A}$

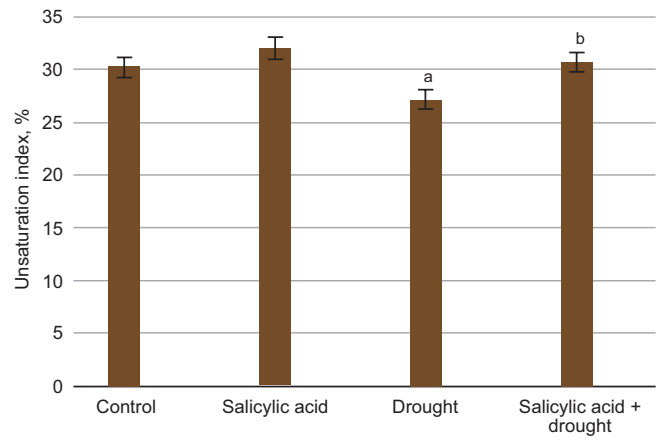

$B$

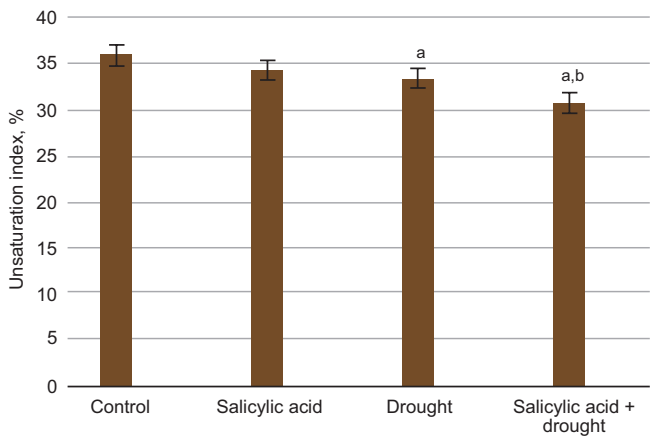

Fig. 6. Lipid unsaturation index under the influence of salicylic acid and drought in the shoots of 12-day-old Zea mays L. (A) and Triticum aestivum L. (B) plants, \%. a - P $<0.05$ (vs control); b $-\mathrm{P}<0.05$ (vs drought)

Рис. 6. Індекс ненасиченості ліпідів за дії саліцилової кислоти і посухи у пагонах 12-добових рослин Zea mays L. (A) i Triticum aestivum L. (B), \%. a - P <0.05 (щодо контролю); b - P <0.05 (щодо посухи)

ISSN 1996-4536 (print) • ISSN 2311-0783 (on-line) • Біологічні Студії / Studia Biologica • 2020 • Том 14/№3 • C. 91-104 
of saturated fatty acids. Under the combined influence of drought and SA, LUI increased significantly compared to its value under the impact of drought alone. The increase in LUI correlated with changes in the accumulation of unsaturated and saturated fatty acids in the shoots of the studied plants.

The determination of LUI in Triticum aestivum L. showed a significant decrease in LUI in the plant shoots as a result of their exposure to moisture deficiency (Fig. 6B). It is mainly due to a sharp decrease in the content of unsaturated fatty acids. At the same time, under the combined influence of SA and drought, LUI decreased even to a greater extent. This reduction was significant in comparison to both control samples and those under the impact of drought. Thus, despite similar trends in the impact of SA and drought on the content of saturated and unsaturated fatty acids in the two studied plant species, some differences have been observed: under the conditions of stress, SA caused an increase in LUI in Zea mays L. and a significant decrease of this indicator in Triticum aestivum $\mathrm{L}$.

Changes in LUI correlated with changes in the content of saturated and unsaturated fatty acids under the influence of SA and drought.

\section{CONCLUSIONS}

It was found that under the conditions of moisture deficiency in the shoots of 12-dayold plants of wheat and corn there was a significant decrease in the total content of saturated and unsaturated fatty acids. Under the action of SA, significant changes in the total content of fatty acids in the shoots of both species were not detected. However, under the combined effect of SA and drought, an increase in the content of saturated and unsaturated fatty acids was observed, which significantly exceeded the content of these compounds under drought conditions.

\section{COMPLIANCE WITH ETHICAL STANDARDS}

Conflict of Interest: The authors declare that the research was conducted in the absence of any commercial or financial relationships that could be construed as a potential conflict of interest.

Animal Rights: This article does not contain any studies with animal subjects performed by the any of the authors.

1. Basu S., Ramegowda V., Kumar A., Pereira A. Plant adaptation to drought stress. F1000 Research, 2016; 5: 1554.

Crossref $\bullet$ PubMed $\bullet$ Google Scholar

2. Bhunia R.K., Chakraborty A., Kaur R., Maiti M.K., Kumar Sen S. Enhancement of a-linolenic acid content in transgenic tobacco seeds by targeting a plastidial $\omega-3$ fatty acid desaturase (fad7) gene of Sesamum indicum to ER. Plant Cell Rep, 2016; 35; 213-226.

Crossref $\bullet$ PubMed $\bullet$ Google Scholar

3. Blokhina O., Virolainen E., Fagerstedt K.V. Antioxidants, oxidative damage and oxygen deprivation stress: a review. Annals of Botany, 2003; 91(2): 179-194.

Crossref • PubMed • Google Scholar

4. Chutipaijit $S$. Changes in physiological and antioxidant activity of indica rice seedlings in response to mannitol-induced osmotic stress. Chilean J. Agric. Res., 2016; 76(4): 455-462. Crossref $\bullet$ Google Scholar

ISSN 1996-4536 (print) • ISSN 2311-0783 (on-line) • Біологічні Студії / Studia Biologica • 2020 • Том 14/№3 • C. 91-104 
5. Cruz R., Golombieski J., Bazana M., Cabreira C., Silveira T., Silva L. Alterations in fatty acid composition due to cold exposure at the vegetative stage in rice. Brazilian Journal of Plant Physiology, 2009; 22: 199-207.

Crossref $\bullet$ Google Scholar

6. Filek M., Walas S., Mrowiec H., Rudolphi-Skórska E., Sieprawska A., Biesaga-Kościelniak J. Membrane permeability and micro- and macroelement accumulation in spring wheat cultivars during the short-term effect of salinity- and PEG-induced water stress. Acta Physiol Plant, 2012; 34: 985-995.

Crossref $\bullet$ Google Scholar

7. Gigon A., Matos A.R., Laffray D., Zuily-Fodil Y., Pham-Thi A.T. Effect of drought stress on lipid metabolism in the leaves of Arabidopsis thaliana (ecotype Columbia). Ann Bot, 2004; 94(3): 345-351.

Crossref $\bullet$ PubMed $\bullet$ Google Scholar

8. Guo Q., Liu L., Barkla B.J. Membrane lipid remodeling in response to salinity. Int J Mol Sci, 2019; 20(17): 4264.

Crossref $\bullet$ PubMed $\bullet$ Google Scholar

9. Hayat S., Hayat Q., Alyemeni M.N., Wani A.S., Pichtel J., Ahmad A. Role of proline under changing environments: a review. Plant Signal Behav, 2012; 7(11): 1456-1466.

Crossref $\bullet$ PubMed $\bullet$ Google Scholar

10. Hong Y., Zheng S., Wang $X$. Dual functions of phospholipase Da1 in plant response to drought. Molecular Plant, 2008; 1(2): 262-269.

Crossref $\bullet$ PubMed $\bullet$ Google Scholar

11. Huang H., Ullah F., Zhou D.X., Yi M., Zhao Y. Mechanisms of ROS regulation of plant development and stress responses. Front Plant Sci, 2019; 10: 800.

Crossref $\bullet$ PubMed $\bullet$ Google Scholar

12. Jiang Y., Huang B. Drought and heat stress injury to two cool-season turfgrasses in relation to antioxidant metabolism and lipid peroxidation. Crop Science, 2001; 41: 436-442.

Crossref $\bullet$ Google Scholar

13. Kachroo A., Kachroo P. Fatty acid-derived signals in plant defense. Annu Rev Phytopathol, 2009; 47: 153-176.

Crossref $\bullet$ PubMed $\bullet$ Google Scholar

14. Kobyletska M., Rybak O., Telegij M. Salicylate activated changes in the intensity of lipid peroxidation in wheat and corn plants in drought condition. Studia Biologica, 2017; 11(3-4): 62-63. (In Ukrainian)

Crossref

15. Kwang-Hyun B., Skinner D.Z. Production of reactive oxygen species by freezing stress and the protective roles of antioxidant enzymes in plants. J. Agr. Chem. Environ., 2012; 1(1): 34-40.

Crossref $\bullet$ Google Scholar

16. Lakyn G.F. Biometrics. Moscow: Vysshaya Shkola, 1990. 352 p. (In Russian)

17. Levishko A.S., Mamenko P.M., Kots S. Ya. Plant metabolomics: fundamentals and role in the study of plant-microbe interactions. Plant Physiology and Genetics, 2014; 46(1): 19-26. (In Ukrainian) Google Scholar

18. Lim G.H., Singhal R., Kachroo A., Kachroo P. Fatty acid- and lipid-mediated signaling in plant defense. Annu Rev Phytopathol, 2017; 55(1): 505-536.

Crossref $\bullet$ PubMed $\bullet$ Google Scholar

19. Malenka U., Kobyletska M., Terek O. Influence of salicylic acid on the amount of free aminoacids and proline in plants of wheat and corn under drought conditions. Studia Biologica, 2014; 8(2): 123-132. (In Ukrainian)

Crossref $\bullet$ Google Scholar

ISSN 1996-4536 (print) • ISSN 2311-0783 (on-line) • Біологічні Студії / Studia Biologica • 2020 • Том 14/№3 • С. 91-104 
20. Molassiotis A., Fotopoulos V. Oxidative and nitrosative signaling in plants: two branches in the same tree? Plant Signal Behav, 2011; 6(2): 210-214.

Crossref $\bullet$ PubMed $\bullet$ Google Scholar

21. Murphy D.J. The biogenesis and functions of lipid bodies in animals, plants and microorganisms. Prog Lipid Res, 2001; 40(5): 325-438.

Crossref $\bullet$ Google Scholar

22. Niu Y., Xiang Y. An overview of biomembrane functions in plant responses to high-temperature stress. Frontiers in Plant Science, 2018; 9: 915.

Crossref $\bullet$ PubMed $\bullet$ Google Scholar

23. Perlikowski D., Kierszniowska S., Sawikowska A., Krajewski P., Rapacz M., Eckhardt Ä., Kosmala A. Remodeling of leaf cellular glycerolipid composition under drought and re-hydration conditions in grasses from the Lolium-Festuca complex. Front Plant Sci, 2016; 7: 1027. Crossref $\bullet$ PubMed $\bullet$ Google Scholar

24. Posmyk M.M., Janas K.M. Effects of seed hydropriming in presence of exogenous proline on chilling injury limitation in Vigna radiata L. seedlings. Acta Physiol Plant, 2007; 29: 509-517. Crossref • Google Scholar

25. Rivis Y.F., Fedoruk R.S. Quantitative chromatographic methods for the determination of individual lipids and fatty acids in biological material. Methodical manual. Lviv. Spolom, 2010. 110 p. (In Ukrainian)

Google Scholar

26. Sahsah Y., Campos P., Gareil M., Zuily-Fodil Y., Pham-Thi A. Enzymatic degradation of polar lipids in Vigna unguiculata leaves and influence of drought stress. Physiologia Plantarum, 2002; 104: 577-586.

Crossref $\bullet$ Google Scholar

27. Shoresh M., Yedidia I., Chet I. Involvement of jasmonic acid/ethylene signaling pathway in the systemic resistance induced in cucumber by Trichoderma asperellum T203. Phytopathology, 2005; 95(1): 76-84.

Crossref $\bullet$ PubMed $\bullet$ Google Scholar

28. Shulaev V., Cortes D., Miller G., Mittler R. Metabolomics for plant stress response. Physiol Plant, 2008; 132(2): 199-208.

Crossref $\bullet$ PubMed $\bullet$ Google Scholar

29. Shulaev V., Oliver D.J. Metabolic and proteomic markers for oxidative stress. New tools for reactive oxygen species research. Plant Physiology, 2006; 141(2): 367-372.

Crossref $\bullet$ PubMed $\bullet$ Google Scholar

30. Stratmann J.W. Long distance run in the wound response - jasmonic acid is pulling ahead. Trends in Plant Science, 2003; 8(6): 247-250.

Crossref • Google Scholar

31. Thi Anh, Silva J., Mazliak P. The role of membrane lipids in drought resistance of plants. Bulletin de la Société Botanique de France. Actualités Botaniques, 2014; 137: 99-114.

Crossref $\bullet$ Google Scholar

32. Upchurch R.G. Fatty acid unsaturation, mobilization, and regulation in the response of plants to stress. Biotechnol Lett, 2008; 30(6): 967-977.

Crossref $\bullet$ PubMed $\bullet$ Google Scholar

33. Wang L., Allmann S., Wu J., Baldwin I.T. Comparisons of LIPOXYGENASE3- and JASMONATE-RESISTANT4/6-silenced plants reveal that jasmonic acid and jasmonic acid-amino acid conjugates play different roles in herbivore resistance of Nicotiana attenuata. Plant Physiol, 2008; 146(3): 904-915.

Crossref $\bullet$ PubMed $\bullet$ Google Scholar

34. Wang Y., Zhang X., Huang G., Feng F., Liu X., Guo R., Gu F., Zhong X., Mei X. Dynamic changes in membrane lipid composition of leaves of winter wheat seedlings in response to PEG-induced water stress. BMC Plant Biol, 2020; 20: 84.

Crossref $\bullet$ PubMed $\bullet$ Google Scholar

ISSN 1996-4536 (print) • ISSN 2311-0783 (on-line) • Біологічні Студії / Studia Biologica • 2020 • Том 14/№3 • C. 91-104 
35. Welti R., Li W., Li M., Sang Y., Biesiada H., Zhou H., Rajashekar C.B., Williams T.D., Wang X. Profiling membrane lipids in plant stress responses. Role of phospholipase $D$ alpha in freezing-induced lipid changes in Arabidopsis. Journal of Biological Chemistry, 2002; 277: 31994-32002.

Crossref $\bullet$ PubMed $\bullet$ Google Scholar

36. Yu B., Lydiate D.J., Young L.W., Schäfer U.A., Hannoufa A. Enhancing the carotenoid content of Brassica napus seeds by downregulating lycopene epsilon cyclase. Transgenic Res. 2008; 17(4): 573-585.

Crossref $\bullet$ PubMed $\bullet$ Google Scholar

37. Zheng G., Tian B., Zhang F., Tao F., Li W. Plant adaptation to frequent alterations between high and low temperatures: remodelling of membrane lipids and maintenance of unsaturation levels. Plant Cell Environ, 2011; 34(9): 1431-1442.

Crossref • PubMed • Google Scholar

\section{ЖИРНОКИСЛОТНИЙ СКЛАД ПАГОНІВ РОСЛИН КУКУРУДЗИ І ПШЕНИЦІ ЗА ДІЇ САЛІЦИЛОВОЇ КИСЛОТИ ЗА УМОВ ПОСУХИ}

\section{М. С. Кобилецька}

Львівський національний університет імені Івана Франка вул. Грушевського, 4, Львів 79005, Україна Кореспондуючий автор: e-mail: myroslava.kobyletska@Inu.edu.ua

Вступ. Саліцилова кислота $є$ природною фенольною сполукою рослинного походження з гормональними властивостями. Саліцилова кислота бере участь у формуванні стійкості рослин до стресорів біотичного й абіотичного походження. Посуха - один із найпоширеніших стресових факторів, який обмежує ріст, розвиток і врожайність рослин. Жирні кислоти $є$ важливими компонентами мембранних органел та плазмалеми. Зміна співвідношення насичених і ненасичених жирних кислот впливає на властивості клітинних мембран і $є$ важливим компонентом формування стійкості рослин до стресових чинників, таких як низька та висока температура, посуха.

Методи. Для дослідження змін жирнокислотного складу, які відбуваються у рослин за дії саліцилової кислоти й посухи, ми визначили вміст жирних кислот у пагонах рослин за допомогою методу газорідинної хроматографії. Досліджено вплив саліцилової кислоти на вміст насичених і ненасичених жирних кислот у пагонах 12-добових рослин Zea mays L. і Triticum aestivum L. за умов посухи. Встановлено, що за умов посухи в пагонах Zea mays L. та Triticum aestivum L. знижується вміст насичених і ненасичених жирних кислот. Водночас саліцилова кислота в концентрації 0,5 мМ ініціювала зростання вмісту цих сполук за стресових умов.

Також визначали індекс ненасиченості ліпідів: співвідношення насичених і ненасичених жирних кислот. Зростання індексу ненасиченості ліпідів під впливом саліцилової кислоти було незначним. Посуха спричинила значне зниження цього показника в пагонах Zea mays L., головно через зменшення пулу насичених жирних кислот. За сумісного впливу посухи і саліцилової кислоти індекс ненасиченості ліпідів значно зростав порівняно з варіантом посухи. Збільшення індексу ненасиченості ліпідів корелює зі змінами нагромадження ненасичених і насичених жирних кислот у пагонах досліджуваних рослин.

ISSN 1996-4536 (print) • ISSN 2311-0783 (on-line) • Біологічні Студії / Studia Biologica • 2020 • Том 14/№3 • C. 91-104 
Результати. Визначення індексу ненасиченості ліпідів у Triticum aestivum L. довело, що у пагонах рослин за впливу дефіциту вологи також спостерігають його достовірне зниження. Насамперед це відбувається внаслідок різкого зниження вмісту ненасичених жирних кислот. Водночас за сумісного впливу саліцилової кислоти і посухи індекс ненасиченості ліпідів ще більше знижується.

Висновок. Незважаючи на подібні тенденції впливу саліцилової кислоти й посухи на вміст насичених і ненасичених жирних кислот у двох досліджуваних видах рослин, у них спостерігали відмінності: за умов стресу саліцилова кислота спричиняла збільшення індексу ненасиченості ліпідів у Zea mays L. і достовірне зменшення цього показника у Triticum aestivum L.

Ключові слова: Zea mays L., Triticum aestivum L., саліцилова кислота, посуха, жирні кислоти 